\section{Analyses of Biofilm on Implant Abutment Surfaces Coating with Diamond-Like Carbon and Biocompatibility}

Patricia Milagros Maquera Huacho ${ }^{1}$, Marianne N. Marques Nogueira', Fernanda G. Basso ${ }^{2}$, Miguel Jafelicci Junior ${ }^{3}$, Renata S. Francisconi ${ }^{2}$, Denise M. P. Spolidorio ${ }^{2}$

\begin{abstract}
The aim of this study was to evaluate the surface free energy (SFE), wetting and surface properties as well as antimicrobial, adhesion and biocompatibility properties of diamondlike carbon (DLC)-coated surfaces. In addition, the leakage of Escherichia coli through the abutment-dental implant interface was also calculated. SFE was calculated from contact angle values; $R_{\mathrm{a}}$ was measured before and after DLC coating. Antimicrobial and adhesion properties against $E$. coli and cytotoxicity of DLC with human keratinocytes ( $\mathrm{HaCaT}$ ) were evaluated. Further, the ability of DLC-coated surfaces to prevent the migration of $E$. coliinto the external hexagonal implant interface was also evaluated. A sterile technique was used for the semi-quantitative polymerase chain reaction (semi-quantitative PCR). The surfaces showed slight decreases in cell viability $(\mathrm{p}<0.05)$, while the $\mathrm{SFE}, R_{\mathrm{a}}$, bacterial adhesion, antimicrobial, and bacterial infiltration tests showed no statistically significant differences ( $p>0.05$ ). It was concluded that DLC was shown to be a biocompatible material with mild cytotoxicity that did not show changes in $R_{\mathrm{a}}$, SFE, bacterial adhesion or antimicrobial properties and did not inhibit the infiltration of $E$. coli into the abutment-dental implant interface.
\end{abstract}

\author{
'Division of Periodontology, \\ Department of Oral Diagnosis \\ and Surgery, Araraquara Dental \\ School, UNESP - Univ Estadual \\ Paulista, Araraquara, SP, Brazil \\ 2Division of Pathology, Department of \\ Physiology and Pathology, Araraquara \\ Dental School, UNESP - Univ Estadual \\ Paulista, Araraquara, SP, Brazil \\ 3Physical Chemical Department, \\ Chemical Institute, UNESP \\ - Univ Estadual Paulista, \\ Araraquara, SP, Brazil
}

Correspondence: Patricia Milagros Maquera Huacho, Rua Humaitá, 1680, 14801-903 Araraquara, SP, Brasil. Tel.: +55-16-3301-6300. e-mail: pattymi_6@hotmail.com

Key Words: microbiology; implantology; prosthodontics; in vitro; diamond-like carbon.

\section{Introduction}

Diamond-like carbon (DLC) is the basis of many studies due to its mechanical, physical and chemical properties, as well as its wide range of applications in electronics and in chemical-, mechanical- and bio-engineering. Thin DLCcoated films have been shown to be biocompatible and to exhibit antimicrobial activity $(1,2)$; they may eliminate Escherichia coli deposited on stainless steel and decrease the biofilm formation (3). The primary killing mechanism was proposed as describing the physical interaction between carbon-based nanomaterials and bacteria, since these nanomaterials can cause irreparable damage to the outer membranes of some Gram-negative bacteria ( $E$. coli and Shewanella oneidensis) $(4,5)$. The DLC films are also considered good candidates for biomedical applications due to their biocompatibility with human cells, which was widely studied. Further, because of their carbon and hydrogen composition, DLC films present optimal cell behavior and high rates of cell proliferation $(3,4,6-9)$.

Although the use of implant-supported prostheses for the treatment of partially or totally edentulous patients has shown success, complications with singleunit prostheses may result in loosened screws, which can cause mechanical complications and inflammation in periimplant tissue and eventually the loss of the implant. If exacerbated, it promotes the infiltration of bacterial flow, regardless the size of the interface between abutments and dental implants and the type of prosthetic connection (10). Gram-negative bacteria such as $E$. coli, used in this study, have a large size, good mobility and survive in adverse environments; they are able to infiltrate the interior of the interface between abutments and dental implants (24). A protocol to control bacteria and strategies to reduce bacterial adhesion and biofilm formation on the surfaces of fasteners during the treatment and maintenance of implants are needed to improve the long-term survival and the soft tissue health in the treatment of peri-implantitis (11). Even if the relationship between the characteristics of the surfaces and the behavior of biofilm formation has not been well defined, the surface free energy and roughness of surfaces to prevent the accumulation of biofilm are worth mentioning. Previous reports have shown that protein adsorption and bacterial adhesion in vivo may result by a threshold surface roughness of $0.2 \mu \mathrm{m}$ (12).

Thus, if DLC is applied to components of dental implants, it may prevent the migration of bacteria to the interface between the abutment and the dental implant; it may be biocompatible and could contribute to the longevity and success of rehabilitation treatment. So, the objective of this study was to evaluate the preventive action of DLC on the migration of bacteria into the interface between abutments and dental implants. Properties including 
roughness, surface free energy, antimicrobial activity, bacterial adhesion and biocompatibility of DLC coating on titanium surfaces were also investigated and the results were correlated with abutment-implant interface properties.

\section{Material and Methods}

\section{Bacterial Strains and Growth Media}

Escherichia coli ATCC 8739 was grown in brain-heart infusion (BHI) culture medium at $37^{\circ} \mathrm{C}$ for $3 \mathrm{~h}$. Turbidity was measured in a spectrophotometer (Spectrum, SP2000 UV) at $600 \mathrm{~nm}$ (OD600) and was found to be 0.3, corresponding to $1.3 \times 10^{8} \mathrm{CFU} / \mathrm{mL}$.

\section{Cell Culture}

HaCat cells, a human keratinocyte cell line, were maintained in Dulbecco's modified Eagle medium (DMEM) (Sigma Chemical Co., St. Louis, MO, USA) supplemented with 10\% fetal bovine serum (FBS; Invitrogen, Carlsbad, CA, USA), $100 \mathrm{UT} / \mathrm{mL}$ penicillin, $100 \mu \mathrm{g} / \mathrm{mL}$ streptomycin and $2 \mathrm{mmol} / \mathrm{L}$ glutamine (Gibco, Grand Island, NY, USA) in a humidified atmosphere $(5 \%)$ of $\mathrm{CO}_{2}$ at $37^{\circ} \mathrm{C}$. Subsequently, the cells were cultured at a concentration of $5 \times 10^{4}$ cells/ $\mathrm{mL}$ in $75 \mathrm{~cm}^{3}$ flasks.

\section{Preparation of Discs}

Titanium (Ti) discs $(7.5 \mathrm{~mm}$ in diameter and $2 \mathrm{~mm}$ thick) were fabricated (Dentoflex Comércio e Indústria de Materiais Odontológicos Ltda, São Paulo, SP, Brazil) and subjected to polishing and finishing procedures to achieve a low mean roughness; $0.2 \mu \mathrm{m}$ was accepted as the threshold for surface screw prosthetic components (12). All discs were ultrasonically cleaned with distilled water and isopropyl alcohol. CVDentus ${ }^{\oplus}$, (São José dos Campos, SP, Brazil), coated the discs with DLC (Ti-DLC). Subsequently, roughness $\left(R_{\mathrm{a}}\right)$ was also measured by profilometry (Surftest SV-400, Mitutuyo Corp., Kawasaki, Japan). The discs were sterilized by gamma radiation at $25 \mathrm{kGy}$ at the Radiation Technology Center (International Irradiation Association [IPEN-CNEN/SP], Brazil).

\section{Surface Free Energy}

The surface free energy of the discs was calculated from the contact angle $(n=3)$ for each group tested with the following liquids: water, ethylene glycol, polyethylene glycol, and diiodomethane with polarities of 52.20, 19.00, 13.60, and 2.60, respectively. The sessile drop technique (Young-Laplace) was used at $37{ }^{\circ} \mathrm{C}$ in a goniometer (Contact Angle System OCA; DataPhysics Instruments $\mathrm{GmbH}$, Filderstadt, Germany) coupled to a computer with SCA 20 software. For analysis of the physical and chemical characteristics of $\mathrm{Ti}$ and Ti-DLC, four liquids of different polarities were dropped $(0.25 \mu \mathrm{L})$ onto each material test disc and the contact angle between them was measured. Subsequentily, contact angle " $\theta$ " values were obtained from the right and left sides of the image of the droplet formed with different solutions and contact angles average were calculated by the SCA 20 software. After the contact angle had been measured, the arithmetic mean and standard deviation were calculated to obtain the surface free energy of each group of samples by use of the SCA 20 software with the OWRK (Owens-WendtRabel-Kaeble) equation.

\section{Colorimetric Analysis of Methylthiazol Tetrazolium (MTT)}

Biocompatibility testing of the DLC was performed by colorimetric analysis of methylthiazol tetrazolium (MTT). The evaluation of the viability and proliferation of $\mathrm{HaCaT}$ cells was measured by cytochemical activity of succinic dehydrogenase (SDH), which represents the rate of mitochondrial respiration of viable cells. Ti, Ti-DLC discs $(n=24)$ and glass cover slips (control group) were used in this test. The discs were distributed in 24-well microtiter plates. Then, $5 \times 10^{4}$ cells $/ \mathrm{mL}$ were seeded and maintained in a $5 \% \mathrm{CO}_{2}$ atmosphere at $37^{\circ} \mathrm{C}$ for $24 \mathrm{~h}$. After this period, the samples received MTT solution (Sigma Chemical $\mathrm{Co}$, $\mathrm{St}$ Louis, MO, USA) and the cells were incubated for $4 \mathrm{~h}$ at $37^{\circ} \mathrm{C}$. Cell viability was assessed with an ELISA microplate reader (3550-UV ; BIO-RAD, Hercules, CA, USA) at a 570 $\mathrm{nm}$ wavelength.

\section{Bacterial Adhesion Test}

E. coli $\left(1.3 \times 10^{8} \mathrm{CFU} / \mathrm{mL}\right)$ in the $\mathrm{BHI}$ medium was maintained for $1.5 \mathrm{~h}$ in an orbital shaker at $75 \mathrm{rpm}$ at 37 ${ }^{\circ} \mathrm{C}$ for microorganisms to adhere to the surface of the Ti and Ti-DLC discs $(n=24)$. After the adhesion period, the discs were rinsed with sterile phosphate buffered saline (PBS) to remove non-adherent microorganisms. Then, new medium was added and the discs were incubated at $37^{\circ} \mathrm{C}$ for $24 \mathrm{~h}$ at $75 \mathrm{rpm}$. They were then washed with PBS, placed individually in sterile saline and ultrasonicated for $20 \mathrm{~min}$. The resulting material was diluted and plated on $\mathrm{BHI}$ agar for $24 \mathrm{~h}$ at $37^{\circ} \mathrm{C}$ for further quantitative analysis of $\mathrm{CFU} / \mathrm{mL}$.

\section{Antimicrobial Test}

Sterile Ti and Ti-DLC discs $(n=24)$ were distributed in microtiter plates (24 wells) containing $\mathrm{BHI}$ and $E$. coli $\left(1.3 \times 10^{7} \mathrm{CFU} / \mathrm{mL}\right)$ and maintained at $37^{\circ} \mathrm{C}$ for $3 \mathrm{~h}$ and $24 \mathrm{~h}$. Gentamycin at $100 \mathrm{~g} / \mathrm{mL}$ (Sigma Chemical Co.) was used as positive control. After the incubation period, aliquots were removed from each well and read by an ELISA reader at $570 \mathrm{~nm}$ (Ascent 354 Multiskan; Labsystems CE, 
Les Ulis, France). For the CFU/mL counting, aliquots from each period were removed, plated on $\mathrm{BHI}$ agar medium and maintained at $37^{\circ} \mathrm{C}$ for $24 \mathrm{~h}$.

Microbiological Analysis: Bacterial Leakage at Implants with External Hexagon-Abutment Connections

In the present study, external hexagon implants $4.0 \mathrm{~mm}$ in diameter and $13 \mathrm{~mm}$ long $(\mathrm{n}=28)$ with their respective anti-rotational abutment were used (Dentoflex). Fourteen screws and surfaces of the implant and the abutments in contact with them were coated with DLC film. During the experimental stages, biosafety standards were adopted.

The implants were fixed in a "bench vise" and the abutments were carefully connected to the implant with a digital torque meter to $32 \mathrm{Ncm}$ (TQ-680; Instrutherm,São Paulo, SP, Brazil), according to the manufacturer's protocol. The assemblies were suspended and stabilized in a glass beaker by a special device manually made from orthodontic chromium nickel (CrNi) wire and wire mesh, so that only the region of the interface between the abutment and dental implant had contact with the culture medium, whether or not it was contaminated with E. coli.

All groups were submerged in sterile BHI broth, and the test groups were inoculated with E. coli $\left(1.3 \times 10^{7}\right.$ $\mathrm{UFC} / \mathrm{mL}$ ) and maintained at $37^{\circ} \mathrm{C}$ for $24 \mathrm{~h}$. Subsequently, the joint surfaces were removed and washed twice with sterile saline solution and cleaned with sterile gauze to remove the biofilm from the external surfaces. Each set was disconnected and the components (implant, screw and abutment) were placed individually in sterile saline and maintained in ultrasonic bath for $10 \mathrm{~min}$. Subsequently, aliquots of the samples were removed by serial dilution, plated on $\mathrm{BHI}$ agar medium and maintained for $24 \mathrm{~h}$ at $37^{\circ} \mathrm{C}$; then, they were quantified in $\mathrm{CFU} / \mathrm{mL}$.

\section{Microbiological Analysis: Preparation of Collected Samples for DNA Extraction}

To check for contamination by $E$. coli within the implant-abutment joint, PCR was used. Bacterial samples from the implant-abutment joint were collected, centrifuged, re-suspended in sterile PBS and frozen at -20 ${ }^{\circ} \mathrm{C}$. Later, DNA extraction was performed by heating the samples at $97^{\circ} \mathrm{C}$ for $10 \mathrm{~min}$ (Thermomixer; Biorresearch, São Paulo, SP, Brazil).

Aliquots of the samples were placed in phenol/ chloroform/isoamyl alcohol (25:24:1) and centrifuged. Next, DNA precipitation was performed at $-20^{\circ} \mathrm{C}$, with the addition of 0.25 volumes of $\mathrm{NaCl}(5 \mathrm{M})$ and 2.5 volumes of cold absolute ethanol. After this period, the samples were centrifuged and the DNA was washed with 75\% ethanol. The final pellet was re-suspended in TE $(10 \mathrm{mM}$ Tris- $\mathrm{HCl}$,
$\mathrm{pH}$ 8.0, $1 \mathrm{mM}$ EDTA, $\mathrm{pH}$ 8.0) and frozen at $-20{ }^{\circ} \mathrm{C}$ until later use. The same procedure was used for purifying DNA from the $E$. coli bacterial strain (ATCC 8739), which was used as a positive control.

\section{Semi-quantitative Polymerase Chain Reaction - PCR}

The sequence of primers used for $E$. coli $16 \mathrm{~S} 14 \mathrm{~F}$ was as follows: 5' CTTGTACACACCGCCCGTC $3^{\prime}$ and 23S1R 5' GGGTTCCCCATTCGGAAATC 3' (Life Technologies of Brazil, Ltda). The oligonucleotides were dissolved in sterile solution containing Tris- $\mathrm{HCl}(10 \mathrm{mM}, \mathrm{pH} 7.6)$ and EDTA (1 $\mathrm{mM}, \mathrm{pH}$ 8.0).

PCR was performed in a final volume of $25 \mu \mathrm{L}$, containing approximately $1 \mu \mathrm{L}$ of each oligonucleotide (Invitrogen Tech-Line ${ }^{S M}$ ), $10.5 \mu \mathrm{L}$ dNTPs (Invitrogen Tech-Line ${ }^{\mathrm{SM}}$ ), from 1 to $2.5 \mu \mathrm{L}$ of $\mathrm{Mg}^{2+}$ and $0.2 \mu \mathrm{L}$ of Taq DNA polymerase (Invitrogen Tech-Line ${ }^{S M}$ ). All reactions were performed in the presence of a positive control containing specific genomic DNA of this bacteria and a negative control without a DNA template. Thermocycling regimen was $94{ }^{\circ} \mathrm{C}$ for $3 \mathrm{~min}, 35$ cycles at $94{ }^{\circ} \mathrm{C}$ for 45 $\mathrm{s}, 55^{\circ} \mathrm{C}$ for $30 \mathrm{~s}$ and $72{ }^{\circ} \mathrm{C}$ for $1.5 \mathrm{~min}$. The presence of the amplified DNA was observed via electrophoresis using 1.5\% agarose gel (Invitrogen Tech-Line ${ }^{\mathrm{SM}}$ ), along with Sybr Safe DNA gel stain 10000X (Invitrogen Tech-Line ${ }^{S M}$ ). The 100-bp marker (GibcoBRL) was used as a molecular weight standard. The bands on the gel were observed in the UV light transilluminator and the images were scanned using Vision Works LS Version 5.5.4 software.

\section{Statistical Analysis}

A statistical analysis was performed for the data of quantitative variables by means of both nonparametric (Mann-Whitney U) and parametric tests (Student's $t$ test) for analysis of the results. Data were expressed as mean \pm standard deviation. All statistical tests were considered at a significance level of $5 \%(p<0.05)$.

\section{Results}

Surface Roughness, Contact Angle Measurements and Surface Free Energy

The results of surface roughness $\left(R_{\mathrm{a}}\right)$, contact angle of the tested liquids (water, ethylene glycol, polyethylene glycol, and diiodomethane), and surface free energy (SFE) on the surfaces of Ti and Ti-DLC discs are reported in Table 1. The $R_{\mathrm{a}}$ values were 0.15 and $0.14 \mu \mathrm{m}$ for Ti and Ti-DLC surfaces, respectively, and were not significantly different $(p>0.05)$. The surfaces presented the highest contact angle values with water and the lowest ones with hydrophobic wet agents and there were no statistically significant differences ( $p>0.05)$ between groups. The SFE for each tested surface was calculated based on the polarity of the 
liquids tested by the OWRK (Owens-Wendt-Rabel-Kaeble) equation. The obtained values of 5.4 and $5.6 \mathrm{mN} / \mathrm{m}$ for Ti and Ti-DLC, respectively, corresponded to the evaluated capacities of the polar surfaces.

\section{Biocompatibility}

The viability of human keratinocytes (HaCat) grown on discs of Ti, Ti-DLC and control discs, was assessed by the MTT assay. The surfaces of Ti and Ti-DLC discs showed respective decreases in cell viability of $58.99 \%$ and $66.07 \%$, and presented a statistically significant difference compared with the control (Table 2). Thus, both tested surfaces showed mild toxicity. Statistical analysis revealed no significant differences between the two experimental groups ( $p>0.05)$.

\section{Antimicrobial and Anti-Adhesive Properties}

In the antimicrobial test, there was no inhibition of E. coli in the tested groups during the review periods of

Table 1. Means and standard deviation (SD) of surface roughness $(\mu \mathrm{m})$ and contact angles (degree) of Ti and Ti-DLC groups

\begin{tabular}{|c|c|c|}
\hline Groups & $\mathrm{Ti}$ & Ti-DLC \\
\hline Surface roughness $(\mu \mathrm{m})$ & $0.15 \pm 0.03$ & $0.14 \pm 0.02$ \\
\hline \multicolumn{3}{|l|}{ Contact Angle (degree) } \\
\hline Water & $74.8 \pm 4.0$ & $69.9 \pm 4.1$ \\
\hline Ethylene glycol & $25.8 \pm 5.9$ & $24.1 \pm 2.7$ \\
\hline Polyethylene glycol & $27.2 \pm 7.1$ & $21.9 \pm 3.5$ \\
\hline Diiodomethane & $23.8 \pm 2.5$ & $19.6 \pm 1.4$ \\
\hline $\begin{array}{l}\text { Surface free } \\
\text { energy }(\mathrm{mN} / \mathrm{m})\end{array}$ & 5.4 & 5.6 \\
\hline
\end{tabular}

*Note: The surface free energy $(\mathrm{mN} / \mathrm{m})$ is shown as the value of its polar component ( $t$ test, $\mathrm{p}>0.05$ ).

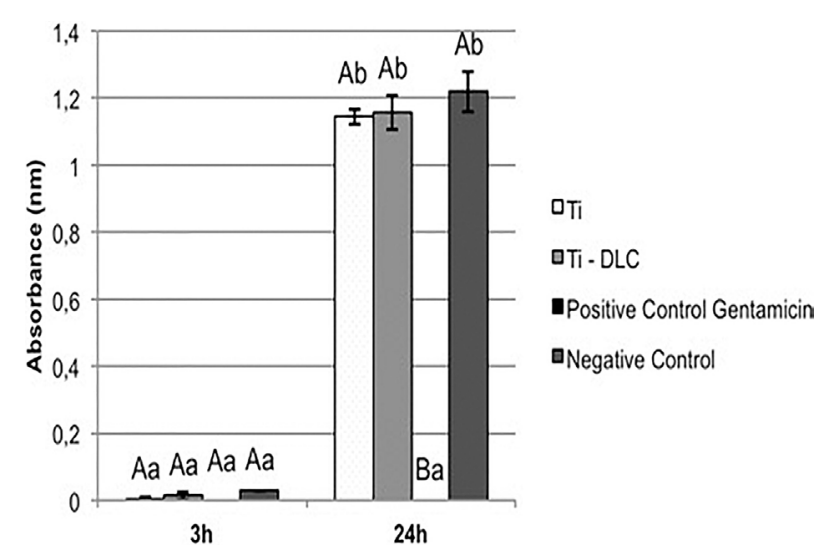

Figure 1. Inhibition of bacterial growth after $3 \mathrm{~h}$ and $24 \mathrm{~h}$ of incubation for Ti and Ti-DLC groups. Columns represent means and error bars represent standard deviations (Mann-Whitney, t test, $\mathrm{p}>0.05$ ).
$3 \mathrm{~h}$ and $24 \mathrm{~h}$ (Fig. 1). The positive and negative control groups corresponded to the gentamycin and BHI cultures, respectively.

The adhesion of E. coli did not decrease on the surfaces of Ti-DLC discs compared with the clean surface of Ti discs and the values were approximately between 7 and $7.2 \mathrm{log}$ (CFU/mL) (Fig. 2).

\section{Bacterial Infiltration}

After $24 \mathrm{~h}$ of incubation in a medium containing E. coli, all dental implants with their respective abutments were disconnected and all sets showed bacterial infiltration. The average values of viable $E$. coli present in the interface between abutment and dental implant are shown in Fig. 3. The analysis showed no statistically significant difference between the tested groups ( $p>0.05$ ).

Microbiological analysis by semi-quantitative PCR with the specific primer for $E$. coli showed presence of positive DNA in 100\% of the tested samples of both groups, confirming the contamination at the interface between the abutment and dental implant (Fig. 4).

\section{Discussion}

Table 2. Cell viability (\%) as determined by the MTT assay

\begin{tabular}{lc}
\hline Treatment & Cell viability (\%) \\
\hline Glass cover slip & $99.26(85.99-114.07) \mathrm{A}^{*}$ \\
$\mathrm{Ti}$ & $58.99(56.28-72.99) \mathrm{B}$ \\
$\mathrm{Ti}$ - DLC & $66.07(58.51-70.08) \mathrm{B}$ \\
\hline
\end{tabular}

*Note: Different capital letters represent statistically significant differences between the cell biomasses in the tested groups (MannWhitney, $p>0.05$ ).

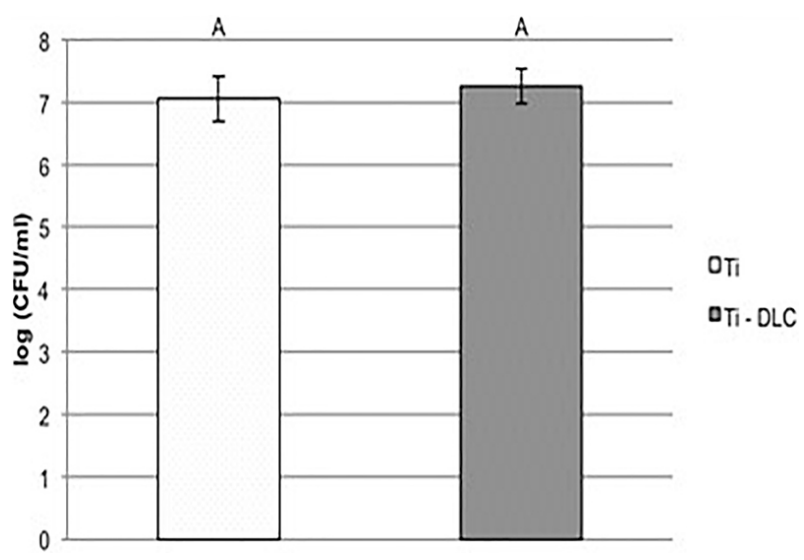

Figure 2. Microorganisms adhering (CFU) to the disc surfaces coated with Ti and Ti-DLC. Columns represent means and error bars represent standard deviations (t test, $\mathrm{p}>0.05$ ). 
In this study, surfaces coated with diamond-like carbon (DLC) were evaluated because the technique has recently attracted attention due to its unique physical, chemical and mechanical properties and it may be applied in many different areas of health care, including dentistry. According to the method of preparation and deposition, the DLC may have different characteristics and properties. Contradictory results have been found regarding the effect of the DLC coating (7). In this study, the samples were coated with DLC by CVDentus ${ }^{\circledR}$ by means of technical chemical vapor deposition (CVD).

Antimicrobial tests on DLC-coated surfaces showed antibacterial properties when tested with $E$. coli (5). The total increase in biomass growing in a liquid medium bacterial culture can be monitored by the measurement of optical density (absorbance). Figure 1 shows that none of the tested groups was able to inhibit bacterial growth. Different authors $(5,13)$ have reported that DLC films exhibit antibacterial activity of $33 \%$ in a $3 \mathrm{~h}$ incubation, which differs from the results of this study. The methodology applied in the present study (in terms of bacterial strain, culture medium and the microorganism concentration) was the same as that used in the studies mentioned above.

Bacterial adhesion on a given surface depends on many factors, including the specific characteristics of the bacterial strains as well as the type of biomaterial. The ability of the biomaterial to resist bacterial adherence is one of the factors that can influence colonization or bacterial infection (14). The free surface energy and roughness of surfaces are important aspects in preventing the adhesion of biofilm and were shown as having direct impact on the adhesion phase in bacteria. A relationship between the types of substrates and the bacterial species has been studied (15) and surface roughness above a threshold of $0.2 \mu \mathrm{m}$ can influence the initial phase of bacterial adherence; hence, in this study,

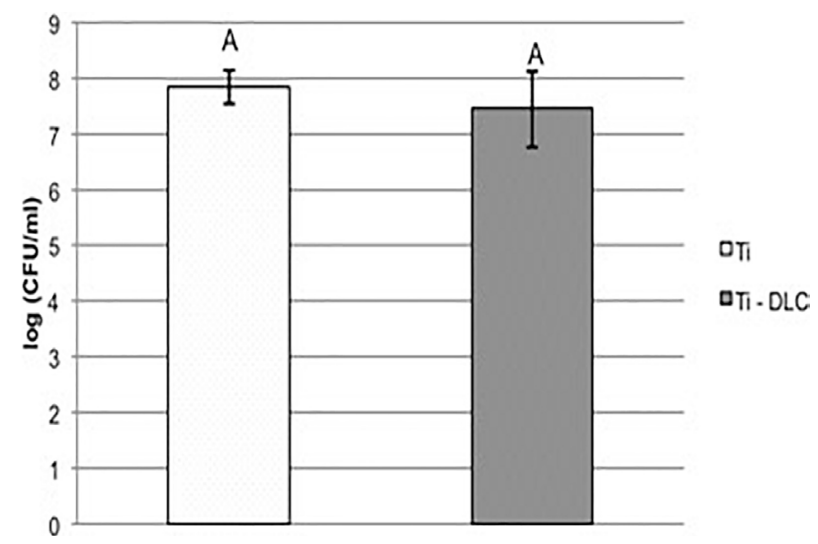

Figure 3. Columns represent means and error bars represent standard deviations for the presence of E. coli $(\log \mathrm{CFU} / \mathrm{mL})$ after $24 \mathrm{~h}$ of incubation in the Ti-DLC and Ti groups ( $t$ test, $\mathrm{p}>0.05)$. titanium discs with mean roughness values of $0.15 \pm 0.03$ $\mu \mathrm{m}$ (Table 1) were used. The results showed that after the DLC coating, these films showed no significant changes in values of roughness values, indicating that the surface properties of the DLC coating did not have a significant influence on bacterial adherence. These findings contradict those of other studies $(14,16)$ that evaluated DLC surfaces and showed that they exhibited high resistance to bacterial adherence of S. aureus and S. epidermidis. Conversely, multispecies anaerobic microorganisms in biofilms on DLC surfaces have demonstrated that the surfaces were unable to reduce bacterial adherence (17). The determination of the antibacterial DLC coating surfaces with only single species testing cannot be considered a basis for in vivo response, since the oral microbiota includes a variety of microorganisms.

Different intermolecular forces can define how bacteria interact with a specific type of surface. Consequently, the interactions can be stronger or weaker, depending on the characteristics of these forces. In this study of E. coli, Gramnegative bacteria were used. These species possess a thinner peptidoglycan layer and an outer membrane that consists of proteins, phospholipids and lipopolysaccharides (LPS) (18), which have a negative net change that contributes to hydrophilic characteristics (19). According to the results of this study, the average contact angle (Table 1) showed that Ti and Ti-DLC surfaces have characteristically high hydrophobic and lipophilic values that could have influenced the ability of $E$. colito adhere to these materials. These results corroborate those of another study (20) showing similar values for the contact angle with water in DLC-coated surfaces, with values of $69.9 \pm 4.1$.

The OWRK equation is most commonly used in the literature for the determination of the surface free energy (21), suggesting that the polarities of the surfaces are an

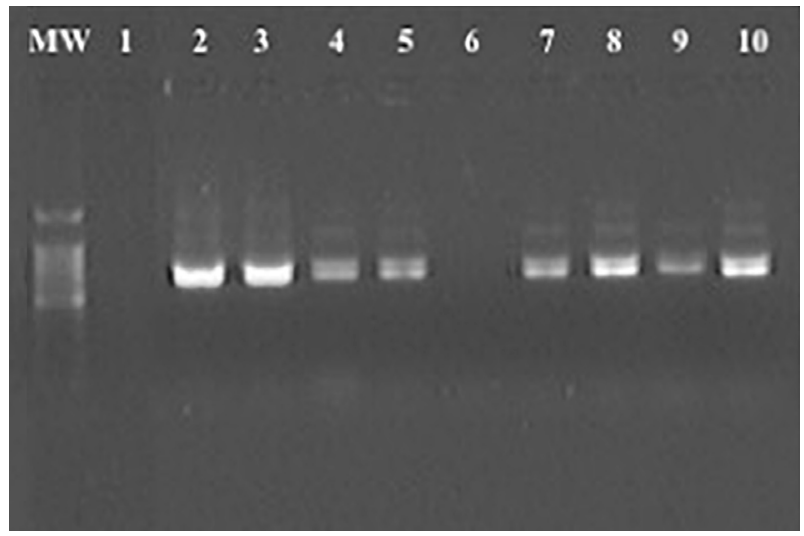

Figure 4. Semi-quantitative PCR for the detection of $E$. coli in the dental implant-abutment joint. MW: molecular-weight standard (100-bp ladder); lines 2-5, Ti-DLC testing group; lines 7-10, Ti control group. 
important part of solid-liquid interactions. Thus, the polar components of the tested samples (Table 1) showed values of 5.4 and $5.6 \mathrm{mN} / \mathrm{m}$ for Ti and Ti-DLC, respectively, without any significant difference. Diab Al Radha et al. (22) found similar values $(5.19 \mathrm{mN} / \mathrm{m})$ for the polar component in titanium samples with average roughness values of less than $0.2 \mu \mathrm{m}$; this was the same pattern and results seen in this study. Moreover, Podgornika et al. (21) assessed steel surfaces coated with DLC by the CVD technique, and found a value of $10 \mathrm{mN} / \mathrm{m}$ for the polar component. As shown, DLC coating on titanium samples does not modify the surface properties of the material, considering the surface free energy.

In vitro studies evaluated the biocompatibility of the materials by cell viability tests with the MTT assay. Marciano et al. (1) and Wachesk et al. (2) noticed that the first time period $(24 \mathrm{~h})$ is essential for cell adhesion due to the migration and proliferation of cells on the surface. The results of the viability of human keratinocytes (HaCat) evaluated on Ti and Ti-DLC discs indicated that the DLC coating does not affect cell response when compared with titanium discs. According to the ISO 10993-5 2009 Standard: Biological Evaluation of Medical Devices: In vitro Methods, the reference value of $99.26 \%$ was used in the present study for cell viability (control); thus, it can be stated that both surfaces tested showed mild toxicity. These results agree with those of previous studies, which also found that for in vitro studies, the biocompatibility of DLC films is well-tolerated and does not cause adverse effects $(8,14)$. However, information about the effect of DLC on cellular metabolism is scarce, as are in vivo studies of DLC. Additional testing is required to confirm cellular integrity, such as tests that prove the structural and functional integrity of the biological material.

The presence of microbial colonization in the dental implant-abutment interface contributes to periimplant inflammation, which may result in serious clinical complications. Leonhardt et al. (23), reported that microorganisms not associated with periodontitis caused more than $50 \%$ of peri-implant lesions; enteric bacteria such as E. coli and E. cloacae were shown to exist in the lesions. E. coli, used in this study, is motile and its physiological characteristics associated with survival in adverse environments guarantee the possibility of infiltration inside the dental implant-abutment interface, which ranges from $1 \mathrm{~mm}$ to $10 \mathrm{~mm}$ (24). In bacterial infiltration tests, the method of infiltration from the external to the internal environment was established by simulation of the in vivo process. After $24 \mathrm{~h}$ of contact with the bacterial suspension, the external surfaces of the sets were manually decontaminated, because the objective was to evaluate only the dental implantabutment interface; however, this procedure could have influenced the results, due to different forces applied by the operator. The maladaptation of dental implantabutment joints may be caused by loosening of the screws and thus can cause mechanical or inflammatory disease complications. This is related to the amount of bacterial leakage where the torque is directly applied (10). However, the amount of torque used in this study was set according to the manufacturer's instructions; thus, all sets would have received the same applied force. In Figure 3, both groups show bacterial infiltration; the coating of the screw as well as the contact areas coated with DLC had no antibacterial characteristics and DLC did not prevent bacterial infiltration into the interface. These results corroborate the findings of Neves et al. (24), who evaluated microleakage in external hexagonal dental implants using screws with and without DLC coating and found no significant differences. Thus, it seems that coating surfaces with DLC have no bactericidal effect on the evaluated groups. The whole procedure was developed according to established biosafety standards to avoid external contamination; however, no external contamination was observed and none was excluded. This result was also supported by a microbiological analysis with semi-quantitative PCR in which the results showed that all samples were contaminated with E. coli and not by other microorganisms from the outside environment.

There are few studies in the literature focusing on the effect of this type of film applied on dental implants and abutments. The results of this study show divergences of the physical and chemical properties of DLC compared with those reported in the existing literature. In contrast, there are several techniques used to produce DLC, which may result in different characteristics and properties. Even so, further studies are required to clarify important characteristics of the DLC, including delamination and various films thicknesses or application of this material to abutments and dental implants of different materials. Thus, this study provides additional information about DLC and its application to material surfaces in health care and dentistry settings.

The results showed that diamond-like carbon (DLC) does not modify roughness and surface free energy applied to titanium surfaces. Also, this material has shown to be biocompatible, with mild cytotoxicity. DLC has no antimicrobial properties and does not interfere with bacterial adhesion when tested against Escherichia coli. Similarly, the DLC coating on the bolt and areas of contact (dental implant-abutment joint) does not exhibit antimicrobial properties and does not inhibit bacterial leakage in this interface. 


\section{Resumo}

0 objetivo deste trabalho foi avaliar a energia livre de superfície (ELS), molhabilidade e propriedades de superfície assim como propriedades antimicrobianas, de adesão e biocompatibilidade de superficies recobertas com Diamond-Like Carbon (DLC). Além disso, investigou-se a infiltração de Escherichia coli por meio da interface abutment-implante dentário. ELS foi calculada a partir dos valores de ângulo de contato; $R_{a}$ foi medida antes e depois do revestimento com DLC. Foram avaliadas propriedades antimicrobianas e de adesão contra $E$. coli e citotoxicidade do DLC utilizando queratinócitos humanos (HaCaT). Além disso, também avaliamos a capacidade para impedir a migração de $E$. coli na interface do implante hexágono externo. Uma técnica estéril foi utilizada para a reação em cadeia da polimerase semi-quantitativa (PCR semi-quantitativo). As superfícies mostraram uma ligeira diminuição da viabilidade celular $(p<0,05)$, enquanto a $E L S, R_{a}$ adesão bacteriana, testes antimicrobianos e de infiltração não apresentaram diferenças estatisticamente significativas $(p>0,05)$. Concluiu-se que o DLC demonstrou ser um material biocompativel levemente citotóxico que não mostra alterações na $R_{a r}$ ELS, adesão bacteriana ou propriedades antimicrobianas e não inibiu a infiltração de $E$. coli na interface abutment-implante dentário.

\section{Acknowledgements}

The authors thank the companies Dentoflex Comércio e Indústria de Materiais Dentários, CVDentus ${ }^{\circledR}-\mathrm{CVDV}$ ale and Radiation Technology Center, and CTR/IPEN-CNEN/SP Brazil for their collaboration and available equipment for the development of this research.

\section{References}

1. Marciano FR, Wachesk CC, Lobo AO, Trava-Airoldi VJ, Pacheco-Soares C, Da-Silva NS. Thermodynamic aspects of fibroblastic spreading on diamond-like carbon films containing titanium dioxide nanoparticles. Theor Chem Acc 2011;130:1085-1093.

2. Wachesk CC, Pires CAF, Ramos BC, Trava-Airoldi VJ, Lobo AO, PachecoSoares $C$, et al.. Cell viability and adhesion on diamond-like carbon films containing titanium dioxide nanoparticles. Appl Surf Sci 2013;266:176-181.

3. Myllymaa K, Levon J, Tiaien VM, Myllymaa S, Soininen A, Korhonen $H_{\text {, }}$ et al.. Formation and retention of Staphylococcal biofilms on DLC and its hybrids compared to metals used as biomaterials. Colloids Surf B Biointerfaces 2013;101:290-297.

4. Kang S, Pinault M, Pfefferle LD, Elimelech M. Single-walled carbon nanotubes exhibit strong antimicrobial activity. Langmuir 2007;23:8670-8673.

5. Lan W-C, Ou S-F, Lin M-H, Ou K-L, Tsai M-Y. Development of silvercontaining diamond-like carbon for biomedical applications. Part I: microstructure characteristics, mechanical properties and antibacterial mechanisms. Ceram Int 2013;39:4099-4104.

6. Yin Y, Hang L, Xu J, McKenzie DR, Bilek MMM. Surface adsorption and wetting properties of amorphous diamond-like carbon thin films for biomedical applications. Thin Solid Films 2008;516:5157-5161.

7. Chai F, Mathis N, Blanchemain N, Meunier C, Hildebrand HF. Osteoblast interaction with DLC-coated Si substrates. Acta Biomater 2008;4:13691381.

8. Calzado-Martín A, Saldaña $L$, Korhonen $H$, Soininen A, Kinnari

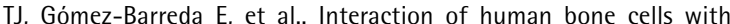
diamond-like carbon polymer hybrid coatings. Acta Biomater 2010;6:3325-3338

9. Manhabosco TM, Martins LAM, Tamborim SM, Ilha M, Vieira MQ, Guma FCR, et al.. Cell response and corrosion behavior of electrodeposited diamond-like carbon films on nanostructured titanium. Corros Sci 2013;66:169-176.

10. Passos SP, Gressier May L, Faria R, Özcan M, Bottino MA. Implantabutment gap versus microbial colonization: clinical significance based on literature review. J Biomed Mater Res B Appl Biomater 2013;101:1321-1328.

11. Paolantonio M, Perinetti G, D'Ercole S, Graziani F, Catamo G, Sammartino $G$, et al.. Internal decontamination of dental implants: An in vivo randomized microbiologic 6-month trial on the effects of a chlorhexidine gel. J Periodontol 2008;79:1419-1425.

12. Quirynen $M$, Bollen $C M$. The influence of surface roughness and surface-free energy on super- and subgingival plaque formation in man. A review of the literature. J Clin Periodontol 1995;22:1-14

13. Marciano FR, Lima-Oliveira DA, Da-Silva NS, Diniz AV, Corat EJ, Trava-Airoldi VJ. Antibacterial activity of DLC films containing $\mathrm{TiO} 2$ nanoparticles. J Colloid Interface Sci 2009;340:87-92.

14. Levon J, Myllymaa K, Kouri VP, Rautemaa R, Kinnari T, Myllymaa S, et al.. Patterned macroarray plates in comparison of bacterial adhesion inhibition of tantalum, titanium, and chromium compared with diamond-like carbon. J Biomed Mater Res: Part A 2010;92:1606-1613.

15. de Avila ED, de Molon RS, Spolidorio DMP, Mollo FD. Implications of surface and bulk properties of abutment implants and their degradation in the health of periodontal tissue. Materials 2013;6:59515966.

16. Soininen A, Levon J, Katsikogianni M, Myllymaa K, Lappalainen R, Konttinen YT, et al.. In vitro adhesion of staphylococci to diamond-like carbon polymer hybrids under dynamic flow conditions. J Mater Sci Mater Med 2011;22:629-636.

17. Almaguer-Flores A, Olivares-Navarrete R, Lechuga-Bernal A, XiménezFyvie LA, Rodill SE. Oral bacterial adhesion on amorphous carbon films. Diam Relat Mater 2009;18:1179-1185.

18. Beveridge TJ. Structures of gram-negative cell walls and their derived membrane vesicles. J Bacteriol 1999;181:4725-4733.

19. Ferris FG, Beveridge TJ. Binding of a paramagnetic metal cation to Escherichia coli K-12 outer-membrane vesicles. FEMS Microbiol Lett 1984;24:43-46.

20. Zhao Q, Liu Y, Abel EW. Effect of temperature on the surface free energy of amorphous carbon films. J Colloid Interface Sci 2004;280:174-183.

21. Podgornik B, Zajec B, Strnad S, Stana-Kleinschek K. Influence of surface energy on the interactions between hard coatings and lubricants. Wear 2007;262:1199-1204

22. Al-Radha AS, Dymock D, Younes C, O'Sullivan D. Surface properties of titanium and zirconia dental implant materials and their effect on bacterial adhesion. J Dent 2012;40:146-153.

23. Leonhardt A, Dahlén $G$, Renvert $S$. Five-year clinical, microbiological, and radiological outcome following treatment of peri-implantitis in man. J Periodontol 2003;74:1415-1422.

24. Neves FD, Prudente MS, Carneiro TAPN, Silva Neto JP, Penatti MPA Bacterial microleakage in hexagonal implants with different screw surface. Rev Odontol Bras Central 2010;19:119-123.

Received December 21, 2016 Accepted January 252017 